\title{
PENGARUH POTENSI DIRI, LINGKUNGAN SOSIAL DAN KEAKTIFAN BERORGANISASI TERHADAP KEPRIBADIAN GENERASI MUDA BUDDHIS DI KABUPATEN JEPARA
}

\author{
Dewi Ana Puji Rahayu ${ }^{1}$ \\ Prihadi Dwi Hatmono, S.Pd.B., M.Pd. ${ }^{2}$ \\ Tri Yatno, S.Pd.B., M.Si. $\underline{3}$
}

\begin{abstract}
ABSTRAK
Penelitian ini bertujuan untuk mengetahui pengaruh langsung potensi diri terhadap keaktifan berorganisasi, pengaruh langsung lingkungan sosial terhadap keaktifan berorganisasi, pengaruh langsung keaktifan berorganisasi terhadap kepribadian, pengaruh langsung potensi diri terhadap kepribadian, pengaruh langsung lingkungan sosial terhadap kepribadian, pengaruh tidak langsung potensi diri terhadap kepribadian melalui keaktifan berorganisasi, dan pengaruh tidak langsung lingkungan sosial terhadap kepribadian melalui keaktifan berorganisasi. Obyek penelitian adalah generasi muda Buddhis di Kabupaten Jepara.

Metode penelitian ini adalah menggunakan metode penelitian kuantitatif dengan metode survey. Jenis sampel stratified random sampling, yaitu 50 responden dari 120 populasi. Teknik pengumpulan data dari kuesioner, wawancara, dan observasi sebagai data primer. Sedangkan data sekunder diperoleh melalui dokumentasi. Analisis data menggunakan analisis jalur atau Path Analisis. Validitas data menggunakan uji instrumen kepada generasi muda Buddhis di Kabupaten Pati.

Hasil penelitian ini menunjukan bahwa pengaruh langsung potensi diri terhadap keaktifan berorganisasi adalah 0,624, pengaruh langsung lingkungan sosial terhadap keaktifan berorganisasi adalah 0,284, pengaruh langsung keaktifan berorganisasi terhadap kepribadian adalah 0,531 , pengaruh langsung potensi diri terhadap kepribadian adalah 0,244 , pengaruh langsung lingkungan sosial terhadap kepribadian adalah 0,228, pengaruh tidak langsung potensi diri terhadap kepribadian melalui keaktifan berorganisasi adalah 0,331344, pengaruh tidak langsung lingkungan sosial terhadap kepribadian melalui keaktifan berorganisasi adalah 0,150804. Kepribadian generasi muda Buddhis di Kabupaten Jepara dipengaruhi oleh potensi diri, lingkungan sosial, keaktifan berorganisasi dan kepribadian.
\end{abstract}

Kata Kunci: Potensi Diri, Lingkungan Sosial, Keaktifan Berorganisasi, Kepribadian.

\footnotetext{
${ }^{1}$ Dharmadutta STABN Raden Wijaya, email: dewianapujirahayu@gmail.com

${ }^{2}$ Dosen STABN Raden Wijaya, email: hatmonoprihadi@gmail.com

${ }^{3}$ Dosen STABN Raden Wijaya, email: triyatno920@yahoo.com
} 


\begin{abstract}
This study aims to determine the potential direct effect of the liveliness organize themselves, the direct influence of the social environment of the activity of organizing, organize direct influence on the personality activeness, potential direct effect on the personality, the direct influence of the social environment on the personality, potential indirect effect on the personality through organizational activeness, and the indirect influence of social environment on the personality through organizational activeness. The object of research is the younger generation of Buddhist Jepara.

This research method is to use quantitative research methods with a survey method. Type sample stratified random sampling, namely 50 respondents of 120 population. Data collection techniques derived from questionnaires, interviews, and observation as the primary data. While the secondary data obtained through documentation. Analysis of data using path analysis or Path Analysis. The validity of the data using a test instrument to the younger generation of Buddhist in Pati regency.

The results of this study indicate that the direct effect of the liveliness organizational potential is 0,624 , the direct influence of the social environment of the activity of organization is 0.284 , direct influence on the personality to organize the activity is 0,531, potential direct effect on the personality is 0,244 , the direct influence of the social environment on the personality is 0.228 , potential indirect effect on the personality through organizational activeness is 0,331344, indirect influence of social environment on the personality through organizational activeness is 0,150804. Personable young Buddhist Jepara influenced by the potential of self, the social environment, active organizations and personalities.
\end{abstract}

Keywords: Potential, Social Environment, activeness Organize, Personality. 


\section{PENDAHULUAN}

Bangsa Indonesia merupakan bangsa yang mempunyai kepribadian dan jati diri. Hal ini tercermin dalam Pancasila yang menjadi pedoman bagi setiap orang. Pancasila sebagai dasar negara berfungsi membentuk kepribadian. Pancasila juga sebagai pandangan hidup bangsa Indonesia yang berfungsi untuk pedoman hidup bagi setiap perilaku bangsa Indonesia dalam berbagai aspek kehidupan (Tim Nasional Dosen Pendidikan Kewarganegaraan, $2010: 2$ ).

Kepribadian manusia dijiwai dengan nilai-nilai Pancasila terutama sila kedua tentang kemanusiaan yang adil dan beradab sebagai landasan kehidupan manusia. Sila ini dijadikan sebagai pedoman bertingkah laku dalam kehidupan bermasyarakat. Terdapat beberapa butir sebagai acuan dalam mewujudkan karakter bangsa, diantaranya adalah mengembangkan sikap tenggang rasa, menjunjung tinggi kemanusiaan, gemar melakukan kegiatan kemanusiaan, berani membela kebenaran dan keadilan serta perlu mengembangkan sikap saling menghormati dan bekerjasama dengan bangsa lain.

Perilaku baik merupakan salah satu wujud dari kepribadian pada generasi muda Buddhis. Para generasi muda Buddhis akan mampu mewujudkan perilaku baik dapat melalui kegiatan berorganisasi. Salah satunya dapat dicermati melalui kegiatan generasi muda Buddhis di Kabupaten Jepara yaitu disebut Sekber PMVBI. Kegiatan Sekber PMVBI dilakukan secara bergantian di vihara-vihara wilayah Kabupaten Jepara.

Berdasarkan pengamatan peneliti pada tanggal 28 Desember 2015 bahwa potensi diri generasi muda Buddhis di Kabupaten Jepara pada saat ini sudah berkembang akan tetapi kemajuan para generasi muda Buddhis belum sempurna. Potensi diri memiliki tingkat pendidikan tinggi dan kemampuan lain seperti seni, budaya, olahraga dan lain-lain. Akan tetapi, hal ini belum maksimal diberdayakan. Diantaranya kurang adanya keseimbangan dalam kemampuan generasi muda Buddhis untuk dapat bertahan menghadapi kesulitan-kesulitan dan kurang mampu mengatasi tantangan dalam menjalankan kehidupan yang baik. Selain itu generasi muda Buddhis juga belum mampu membuat kreativitas sendiri. Artinya generasi muda Buddhis mau berkreativitas karena ada orang yang mau mengajari untuk berkreatif. Apabila tidak ada yang mengajarinya maka generasi muda Buddhis masih ada yang tidak mempunyai inisiatifnya 
untuk menumbuhkan potensi diri itu. Hal ini dapat dipengaruhi oleh kurangnya bersosialisasi terhadap lingkungan.

Generasi muda belum memiliki motivasi dalam kegiatan pertemuan Sekber PMVBI karena kurangnya kerjasama antar pengurus. Kegiatan yang dilaksanakan itu belum terprogram oleh pengurus sehingga kegiatan berjalan kurang maksimal. Hal inilah yang perlu diperhatikan oleh suatu organisasi, karena organisasi itu membutuhkan kerjasma yang baik supaya membawa kemajuan bersama yang lebih baik dalam organisasi tersebut. Selain itu, pengurus juga harus bisa meyakinkan bahwa pertemuan Sekber PMVBI akan membawa manfaat baik bagi setiap orang. Generasi muda Buddhis yang aktif belum mengetahui sepenuhnya tujuan dari kegiatan tersebut. Apabila generasi muda Buddhis mengetahui tujuan dari kegiatan itu maka generasi muda Buddhis akan menjadi lebih bersemangat dalam mengikuti kegiatan tersebut. Sehingga dalam mengikuti kegiatan Sekber PMVBI dapat mengembangkan bakat ataupun potensi berdasarkan kemampuan masing-masing serta dapat belajar mengenai menjadi diri pribadi yang baik, salah satunya adalah bertingkah laku baik dimanapun berada. Memiliki tingkah laku yang baik merupakan salah satu bentuk dari kepribadian seseorang.

Kepribadian merupakan suatu pola tingkah laku seseorang yang telah dilakukan sehari-hari dalam menyesuaikan lingkungannya. Pola tingkah laku setiap orang berbeda-beda dalam menyesuaikan lingkungan diantaranya ada yang sopan, ramah tamah, dan bertanggung jawab maupun yang lainnya. Hal ini juga terjadi di banyak daerah terutama di daerah Kabupaten Jepara, khususnya para generasi muda Buddhis pada Pemuda Pemudi Vihara-vihara Buddhayana Indonesia (PMVBI).

Membentuk perilaku generasi muda Buddhis dapat melalui dengan mengikuti pertemuan Sekber PMVBI. Mengikuti kegiatan ini dapat menimbulkan rasa tanggung jawabnya bertambah, interaksinya terhadap masyarakat, dan lainnya. Beberapa generasi muda Buddhis yang ikut aktif dalam kegiatan pertemuan Sekber PMVBI karena adanya keterpaksaan. Generasi muda Buddhis mau ikut pertemuan Sekber PMVBI karena orangtuanya memberikan motivasi untuk dapat mengikuti pertemuan tersebut. Dengan adanya perintah atau dorongan orangtua maka generasi muda Buddhis ikut aktif dalam pertemuan tersebut. Bila 
tidak diperintah maka generasi muda Buddhis tidak ikut serta dalam pertemuan Sekber PMVBI. Hal ini berdasarkan pengamatan dari peneliti yang dilakukan pada tanggal 27 Desember 2015 di Kabupaten Jepara khususnya para generasi muda Buddhis. Dalam penelitian ini berarti bahwa kepribadian merupakan sikap, tingkah laku seseorang yang dilakukan setiap hari secara terus menerus dan karakteristik seseorang dapat dilihat melalui sikap dan tingkah laku seseorang. Berdasarkan masalahmasalah yang berada di latar belakang tersebut bahwa peneliti mengambil judul pengaruh potensi diri, lingkungan sosial, dan keaktifan berorganisasi terhadap kepribadian generasi muda Budhis di Kabupaten Jepara.

\section{LANDASAN TEORI}

\section{A. Potensi Diri}

Potensi berasal dari bahasa Inggris "to potent" yang berarti kekuatan (powerful), daya, kekuatan, kemampuan. Setiap individu pada hakekatnya memiliki suatu potensi yang dapat dikembangkan, baik secara individu maupun kelompok melalui latihanlatihan (LAN, 2014: 4).

Potensi diri merupakan suatu kemampuan diri yang dimiliki oleh manusia. Oleh karena itu, pengenalan dan pengukuran potensi diri tersebut adalah untuk mengungkap kemampuan yang ada dalam diri. Dengan mengenal dan mengukur potensi diri, antara lain akan memberikan gambaran kepribadian seseorang serta gambaran kecenderungan seseorang dalam berperilaku. Dalam ajaran Buddha tentang pengembangan potensi diri yaitu terdapat dalam Dhammapada XXVI syair 21 bahwa Sang Buddha berkata "seseorang yang pengetahuannya dalam, pandai, dan terlatih dalam membedakan jalan yang benar dan salah, yang telah mencapai tujuan tertinggi, maka ia Kusebut seorang 'brahmana"' (Widya, 2001: 165).

\section{B. Lingkungan Sosial}

ajaran Buddha terdapat di Sagathavagga bagian dari Samyutta Nikaya yang berisi tentang kumpulan orang banyak. Kumpulan orang banyak ini yaitu Sang Buddha sedang berdiam di antara orangorang Sakya di Kapilavatthu, di Hutan Besar bersama dengan sejumlah besar Sangha para Bhikkhu, dengan lima ratus Bhikkhu yang semuanya adalah Arahanta. Para devata dari sepuluh alam 
semesta sebagai kelompok terbesar berkumpul untuk melihat Sang Bhagava dan Sangha. Para devata ini memberikan hormat kepada Sang Bhagava dengan mengucapkan beberapa syair. Salah satu syair yang diucapkan devata yaitu, "Kumpulan besar terjadi di dalam hutan, Para dewa telah berkumpul. Kami datang pada kumpulan Dhamma ini. Untuk melihat Sangha yang tidak terkalahkan." Berdasarkan hal tersebut bahwa perkumpulan banyak orang merupakan suatu lingkungan sosial yang mempengaruhi untuk belajar dan melaksanakan Dhamma (Bodhi, 2010: 94).

$$
\text { Menurut }
$$

Dewantoro

Lingkungan sosial antara lain terdiri dari lingkungan keluarga, lingkungan sekolah, dan lingkungan masyarakat. Lingkungan keluarga merupakan faktor yang pertama dan utama menentukan keberhasilan seseorang.

\section{Keaktifan Berorganisasi}

Keaktifan berasal dari kata "aktif" yang artinya selalu berusaha, bekerja dan belajar dengan sungguh-sungguh supaya mencapai tujuan yang diharapkan.

Menurut Yamin Martimis, (2007: 84) keaktifan dipengaruhi oleh beberapa faktor. Faktor-faktor yang mempengaruhi keaktifan kegiatan dalam organisasi generasi muda adalah a) Memberikan motivasi atau menarik perhatian, sehingga mereka berperan aktif dalam kegiatan organiasasi; b) Menjelaskan tujuan instruksional (kemampuan dasar kepada generasi muda; c) Mengingatkan kompetensi diri kepada generasi muda; d) Memberikan stimulus (masalah, topik, dan konsep yang akan dibahas dalam organisasi); e) Memunculkan aktifitas, partisipasi kegiatan organisai; f) Memberikan umpan balik (feedback).

Berdasarkan penjelasan tersebut maka dapat disimpulkan keaktifan dipengaruhi oleh berbagai macam faktor seperti menarik atau memberikan motivasi kepada generasi muda dan keaktifan juga dapat ditingkatkan, salah satu cara meningkatkan keaktifan yaitu dengan mengajak generasi muda dengan mengembangkan potensinya.

Organisasi berasal dari kata organ dalam bahasa Yunani yang artinya alat. Oleh karena itu dapat didefinisikan bahwa organisasi merupakan sebuah sistem yang terdiri dari sekumpulan individu terhadap pembagian kerja 
kelompok dalam rangka mewujudkan tujuan yang telah diciptakan secara sistematis dan struktural (Fahmi, 2013: 1-2).

\section{Kepribadian}

Kepribadian merupakan suatu keadaan dalam diri seseorang dimana dapat menentukan bagaimana penampilannya dalam menyesuaikan diri dengan lingkungannya (Winarti, 2007: 4).

Dalam agama Buddha terdapat enam carita atau kecenderungan/watak

(Mahavirothavaro, Mettadewi \& Dr. Douglas M. Burns 2009: 63-65) adalah:

a. Raga-carita

b. Dosa-carita,

c. Vitakka-carita,

d. Sadda-carita,

e. Buddhi-carita,

Jadi ke-intelekkan atau kecerdasan harus diimbangi atau disertai dengan pengetahuan benar, pengetahuan yang memberikan gambaran nyata mengenai kehidupan dan fenomena.

\section{METODE PENELITIAN}

Jenis penelitian ini adalah kuantitatif dengan menggunakan metode survai. Metode survai merupakan metode pengumpulan data terhadap sejumlah individu yang dianggap representative dalam mewakili populasinya supaya memperoleh sejumlah nilai-nilai tertentu atas sejumlah variabel yang dipilih (Slamet, 2011: 9).

Strategi yang digunakan dalam meneliti adalah menggunakan analisis path. Menurut Dillon dan Goldstein (1984), analisis path adalah pengembangan dari model regresi yang digunakan untuk menguji bentuk hubungan sebab akibat atau kausal dari beberapa variabel dan kesesuaian dari model tersebut. Dengan analisis path, dapat diestimasi koefisien-koefisien beberapa persamaan struktural linear yang mempunyai hubungan sebab akibat seperti yang sudah dihipotesiskan (Triswianti, 2010: 22). Penelitian ini bertujuan untuk melihat pengaruh potensi diri, lingkungan sosial, dan keaktifan berorganisasi terhadap kepribadian generasi muda Buddhis di Kabupaten Jepara.

Lokasi penelitian dalam penelitian ini di vihara-vihara Buddhayana yang ada di Kabupaten Jepara. Jumlah vihara Buddhayana yang ada di Kabupaten Jepara sekitar 14 vihara, diantaranya vihara Bodhi Kalingga, Jaya Manggala, Tri Dharma Loka, Bodhi Soma Manggala, Giri 
Shanti Loka, Sasana Loka, Eka Metta Loka dan lainnya.

\section{HASIL DAN PEMBAHASAN}

$$
\begin{aligned}
& \text { Pembahasan analisis } \\
& \text { penelitian dalam bab ini akan } \\
& \text { dilakukan dengan melakukan analisis } \\
& \text { terhadap angka-angka yang diperoleh } \\
& \text { untuk dikaji secara teoritis, sehingga } \\
& \text { akan dapat menjelaskan hal-hal yang } \\
& \text { berhubungan dengan penelitian. }
\end{aligned}
$$$$
\text { Berdasarkan }
$$$$
\text { analisis }
$$

penelitian dihasilkan bahwa semua hipotesis yang diajukan diterima, yang menunjukkan bahwa pertama yaitu ada pengaruh langsung potensi diri terhadap keaktifan berorganisasi generasi muda Buddhis di Kabupaten Jepara.Kedua, ada pengaruh lingkungan sosial terhadap keaktifan berorganisasi generasi muda Buddhis di Kabupaten Jepara.Ketiga, ada pengaruh langsung keaktifan berorganisasi terhadap kepribadian generasi muda Buddhis di Kabupaten Jepara.Keempat, ada pengaruh langsung potensi diri terhadap kepribadian generasi muda Buddhis di Kabupaten Jepara.Kelima, ada pengaruh langsung lingkungan sosial terhadap kepribadian generasi muda Buddhis di Kabupaten Jepara.Keenam, ada pengaruh tidak langsung potensi diri terhadap kepribadian melalui keaktifan berorganisasi generasi muda Buddhis di Kabupaten Jepara.Ketujuh, ada pengaruh tidak langsung lingkungan sosial terhadap kepribadian melalui keaktifan berorganisasi generasi muda Buddhis di Kabupaten Jepara.

Berdasarkan uji yang dilakukan dengan Path Analisis bahwa variabel yang mempunyai pengaruh langsung paling kuat terhadap kepribadian adalah variabel keaktifan berorganisasi.Sedangkan pengaruh tidak langsung yang kuat terhadap kepribadian melalui keaktifan berorganisasi adalah variabel potensi diri.

Potensi diri merupakan suatu kemampuan diri yang dimiliki oleh manusia.Oleh karena itu, pengenalan dan pengukuran potensi diri tersebut adalah untuk mengungkap kemampuan yang ada dalam diri. Dengan mengenal dan mengukur potensi diri, maka akan memberikan gambaran kepribadian seseorang serta gambaran kecenderungan seseorang dalam berperilaku (LANRI, 2008: 9). Potensi diri juga diartikan sebagai bakat.Bakat yang dimiliki oleh seseorang merupakan kemampuan alami yang ada dalam dirinya tanpa tergantung pada upaya pendidikan maupun pelatihan (Indriyanti, Siswandari \& Elvia 2013: 
10). Faktor lain yang dapat mengembangkan potensi diri yakni melalui lingkungan. Faktor lingkungan dapat berupa kesempatan, sarana dan prasarana, dukungan orang lain, tempat tinggal, status sosial ekonomi dan sebagainya (Mukti, 2003: 309).

$$
\text { Lingkungan }
$$

menurut

Darsono (Anonim, 2014: 15) merupakan semua benda atau kondisi manusia dan aktivitasnya yang terdapat dalam ruang,dimana manusia tersebut memengaruhi kelangsungan hidupnya.Lingkungan sosial merupakan orang atau masyarakat sekitar yang memiliki segala aspek yang bertalian erat dengan kepribadian manusia serta selalu mempengaruhi perkembangan manusia. Lingkungan sosial merupakan lingkungan kemasyarakatan yang mempunyai kaitan erat dengan kehidupan seharihari. Purwanto (2003: 28) "mengemukan bahwa lingkungan sosial adalah semua orang atau manusia lain yang mempengaruhi kita”. Manusia membentuk pengelompokan sosial diantara sesama dalam upayanya mempertahankan hidup dan mengembangkan kehidupan.Dalam suatu kehidupan sosial manusia juga memerlukan organisasi yaitu sekolah, kelompok masyarakat dan lain-lain (Yuliyatun, 2012: 6-7).

Menurut Yamin Martimis, (2007: 84)keaktifan dipengaruhi oleh beberapa faktor. Faktor-faktor yang mempengaruhi keaktifan berorganisasi dalam organisasi generasi muda adalah a) Memberikan motivasi atau menarik perhatian, sehingga mereka berperan aktif dalam kegiatan organiasasi; b) Menjelaskan tujuan instruksional (kemampuan dasar kepada generasi muda; c) Mengingatkan kompetensi diri kepada generasi muda; d) Memberikan stimulus (masalah, topik, dan konsep yang akan dibahas dalam organisasi); e) Memunculkan aktifitas, partisipasi kegiatan organisai; f) Memberikan umpan balik (feedback).

Keaktifan dapat ditingkatkan dan diperbaiki dalam keterlibatan generasi muda pada saat kegiatan berorganisasi. Hal tersebut seperti dijelaskan oleh Usman (2009: 26-27) cara untuk memperbaiki keterlibatan generasi muda diantaranya yaitu abadikan waktu yang lebih banyak untuk kegiatan generasi muda, tingkatkan partisipasi generasi muda secara efektif dalam kegiatan berorganisasi, serta berikanlah 
motivasi agar generasi muda tetap merasa senang dalam suatu kegiatan. Selain itu, untuk meningkatkan keterlibatan atau keaktifan generasi muda dalam kegiatan berorganisasi adalah mengenali dan membantu generasi muda yang kurang terlibat dan menyelidiki penyebabnya dan usaha apa yang bisa dilakukan untuk meningkatkan keaktifan generasi muda, sesuaikan dengan kemampuan generasi muda. Hal ini sangat penting untuk meningkatkan usaha dan keinginan generasi muda untuk berfikir secara aktif dalam kegiatan berorganisasi.

Kepribadian merupakan suatu keadaan dalam diri seseorang dimana dapat menentukan bagaimana penampilannya dalam menyesuaikan diri dengan lingkungannya (Winarti, 2007: 4).Kepribadian merupakan suatu totalitas psikhophisis yang kompleks dari individu, sehingga nampak di dalam tingkah lakunya yang unik (Sujanto, Halem \& Taufik, 2009).Kepribadian adalah ciri sifat khas diri seseorang yang bersumber dari bentukan-bentukan yang diterima dari lingkungan (Sjarkawi, 2006: 11).Adanya faktor internal dan eksternal ada juga faktor interaksi antara bawaan serta lingkungan.Faktor ini dapat melalui interaksi terus menerus antara bawaan serta lingkungan yang menyebabkan perasaan aku dalam diri seseorang (Winarti, 2007: 5).

Pada penelitian ini, bahwa secara langsung kepribadian dipengaruhi oleh potensi diri sebesar 0,244, secara langsung kepribadian dipengaruhi oleh lingkungan sosial sebesar 0,228, secara lanngsung kepribadian dipengaruhi oleh keaktifan berorganisasi sebesar 0,531, secara tidak langsung kepribadian dipengaruhi oleh potensi diri melalui keaktifan berorganisasi sebesar 0,331344, secara tidak langsung kepribadian dipengaruhi oleh lingkungan sosial melalui keaktifan berorganisasi sebesar 0,150804 .

1. Pengaruh Langsung Potensi Diri terhadap Keaktifan Berorganisasi Generasi Muda Buddhis di Kabupaten Jepara

Potensi diri dapat diukur dengan menggunakan metode self assessment (intropeksi), feed back dan tes psikologis. Selain itu, Potensi diri dapat diukur dengan menggunakan tes phsikologis diantaranya yaitu tipologi (sanguinis, melankolis, kloris, plegmatis), tingkat kepercayaan diri dan ambisi (LANRI, 2008: 
10-11).Sedangkan keaktifan berorganisasi dapat diukur dengan tiga gagasan penting partisipasi yaitu keterlibatan mental atau pikiran, keterlibatan emosi, tanggung jawab.Jadi, potensi diri diukur melalui sifat-sifat, bakat, kepercayaan diri, keinginan kuat yang di miliki oleh diri pribadi para generasi muda Buddhis di Kabupaten Jepara untuk mewujudkan suatu potensi yang diinginkan melalui keaktifan berorganisasi. Dalam uji signifikan koefisien pengaruh, hasil analisis terhadap hipotesis adalah menerima hipotesis pertama yang berarti ada pengaruh langsung yang signifikan potensi diri terhadap keaktifan berorganisasi.Berdasarkan Path Analisis bahwa pengaruh langsung potensi diri terhadap keaktifan berorganisasi sebesar 0,624 .

Menurut Adi W Gunawan ada satu faktor kunci yang menjadi fondasi keberhasilan seseorang dalam bidang apapun yang diinginkannya yaitu pola pikir (LANRI, 2008: 50). Faktor lain yang dapat mengembangkan potensi diri yakni melalui lingkungan. Faktor lingkungan dapat berupa kesempatan, sarana dan prasarana, dukungan orang lain, tempat tinggal, status sosial ekonomi dan sebagainya (Mukti, 2003: 309). Demikian juga yang terjadi di Kabupaten Jepara bahwa generasi muda Buddhis dari 50 responden baik itu tingkat SMP, SMA, dan perguruan tinggi memiliki pola pikir dalam berkarya untuk mewujudkan potensinya yang dimiliki dengan berperan aktif dalam kegiatan pertemuan Sekber PMVBI. Dari data tersebut diolah dengan SPSS 15 yaitu terlihat bahwa potensi diri mempengaruhi keaktifan berorganisasi sebesar 0,624. Artinya, jika variabel potensi diri dinaikkan satu satuan maka keaktifan berorganisasi generasi muda Buddhis di Kabupaten Jeparaakan meningkat sebesar 0,624 .

\section{Pengaruh}

Langsung

Lingkungan Sosial terhadap Keaktifan Berorganisasi Generasi Muda Buddhis di Kabupaten Jepara

$\begin{array}{lr}\text { Lingkungan } & \text { sosial } \\ \text { merupakan } & \text { lingkungan } \\ \text { kemasyarakatan } & \text { yang } \\ \text { mempunyai hubungan } & \text { erat }\end{array}$




dengan kehidupan sehari-
hari.Ada beberapa jenis
lingkungan sosial diantaranya
adalah lingkungan keluarga,
lingkungan sekolah, dan
lingkungan

masyarakat.Sedangkan dalam keaktifan berorganisasi meliputi tiga gagasan penting partisipasi yaitu keterlibatan mental atau pikiran, keterlibatan emosi, tanggung jawab.Berdasarkan hal tersebut bahwa ingkungan sosial pada penellitian ini memang berpengaruh terhadap keaktifan berorganisasi generasi muda Buddhis di Kabupaten Jepara.Dalam uji signifikansi koefisien pengaruh, hasil analisis terhadap hipotesis adalah menerima hipotesis kedua yang berarti ada pengaruh langsung yang signifikan lingkungan sosial terhadap keaktifan berorganisasi.

Keberhasilan seseorang ditentukanoleh beberapa faktor.Faktor pertama yang menentukan keberhasilan seseorang adalah lingkungan keluarga, faktor yang kedua merupakan peran penting dalam mencerdaskan dan membimbing moral perilaku anak adalah lingkungan sekolah, dan faktor yang ketiga yaitu lingkungan sosial karena lingkungan sosial meliputi bentuk kehidupan masyarakat dan teman bergaul (Yuliyatun, 2012: 7). Dalam penelitian ini bahwa generasi muda Buddhis di Kabupaten Jepara mampu menciptakan keharmonisan dalam keluarga dengan saling terbuka, tidak menutupi kebenaran ataupun kesalahan yang ada serta mampu bersosialisasi di sekolah maupun masyarakat yaitu dengan melalui berpartisipasi dalam keaktifan berorganisasi di Sekber PMVBI. Berdasarkan Path Analisis, bahwa pengaruh langsung lingkungan sosial terhadap keaktifan berorganisasi dalam penelitian ini sebesar 0,284. Artinya, jika variabel lingkungan sosial dinaikkan satu satuan maka keaktifan berorganisasi generasi muda Buddhis di Kabupaten Jeparaakan meningkat sebesar 0,284 .

\section{Pengaruh Langsung Keaktifan Berorganisasi terhadap Kepribadian Generasi Muda Buddhis di Kabupaten Jepara}


Keaktifan berorganisasi

adalah kegiatan seseorang yang aktif mengikuti berbagai macam kegiatan yang dilakukan oleh sebuah organisasi, baik kegiatan yang berbentuk formal ataupun non formal untuk menambah wawasan, pengalaman dan pendewasaan dalam diri seseorang.Sedangkan

kepribadian merupakan suatu keadaan dalam diri seseorang dimana dapat menentukan bagaimana penampilannya dalam menyesuaikan diri dengan lingkungannya (Winarti, 2007: 4). Berdasarkan hal ini, bahwa keaktifan berorganisasi generasi muda Buddhisdi Kabupaten Jepara mempengaruhi kepribadian generasi muda Buddhis melalui kegiatan Sekber PMVBI di kota tersebut. Dalam uji signifikansi koefisien pengaruh, hasil analisis terhadap hipotesis adalah menerima hipotesis ketiga yang berarti ada pengaruh langsung yang signifikan keaktifan berorganisasi terhadap kepribadian.

Keaktifan berorganisasi memiliki tiga gagasan penting untuk berpartisipasi pada generasi muda yaitu melalui keterlibatan mental dan emosi, keterlibatan tanggung jawab, dan keterlibatan mental atau pikiran.Hal ini sangat mendukung terhadap keaktifan generasi muda Buddhis di Kabupaten Jepara karena adanya partisipasi anggota organisasi mampu menyampaikan inisiatif dan menyalurkan kreatifitasnya untuk memajukan organisasi. Partisipasi juga mampu mendorong anggota untuk menerima tanggungjawab atas aktifitas yang dilakukan sehingga akan belajar untuk bertanggungjawab dalam menyelesaikan tugasnya.Menurut Winarti (2007: 5) bahwa kepribadian dipengaruhi oleh faktor internal dan eksternal, faktor internal yaitu sifat dari individu supaya dapat berpotensi diri berdasarkan kemampuan yang dimiliki sedangkan faktor eksternal merupakan faktor dari luar yang dapat mempengaruhi kepribadian seperti lingkungan sosial dan keorganisasian.Dalam hasil penelitian ini dapat dilihat berdasarkan Path Analisis, bahwa pengaruh keaktifan 


\begin{tabular}{lrr}
$\begin{array}{l}\text { berorganisasi } \\
\text { kepribadian }\end{array}$ & $\begin{array}{r}\text { terhadap } \\
\text { sebesar }\end{array}$ \\
0,531.Artinya, jika & variabel \\
keaktifan & \multicolumn{2}{c}{ berorganisasi } \\
dinaikkan satu & satuan & maka \\
kepribadian & generasi & muda \\
Buddhis & di & Kabupaten \\
Jeparaakan & meningkat & sebesar \\
$0,531$.
\end{tabular}

\section{Pengaruh Langsung Potensi} Diri terhadap Kepribadian Generasi Muda Buddhis di Kabupaten Jepara

Potensi diri dapat diukur dengan menggunakan metode self assessment (intropeksi), feed back dan tes psikologis. Selain itu, Potensi diri dapat diukur dengan menggunakan tes phsikologis diantaranya yaitu tipologi (sanguinis, melankolis, kloris, plegmatis), tingkat kepercayaan diri dan ambisi (LANRI, 2008: 10-11).Jadi, potensi diri dapat diukur melalui tipologi diri, kepercayaan diri, dan ambisi.Tipologi diri merupakan sifat-sifat yang dapat membentuk kepribadian; kepercayaan diri adalah efek dari bagaimana seseorang merasa ingin tahu, meyakini dan mengetahui tentang tujuan yang diinginkan oleh diri pribadi; ambisi adalah keinginan yangkuat untuk memperoleh kesuksesan dalam hidup danmencapai hal-hal besar/baik yang diinginkan.Sedangkan kepribadian dapat diukur melalui keyakinan individu mengenai kemampuan yang dimiliki, mengatur sumber daya dan mengelola situasi, tetap gigih dalam menghadapi rintangan, memulihkan diri dari keterpurukan(General SelfEfficacy Scale (GSE); penilaian simpati, tenggang rasa, keterandalan, tanggunjawab, keceriaan, kehangatan, asertivitas, adaptasi secara sosial, dan persahabatan (Ego Resiliency Scale); berpikir untuk memahami dan mengevaluasi (Core SelfEvaluations). Dalam uji signifikansi koefisien pengaruh, hasil analisis terhadap hipotesis adalah menerima hipotesis keempat yang berarti ada pengaruh langsung yang signifikan potensi diri terhadap kepribadian.

Menurut Adi W Gunawan ada satu faktor kunci yang menjadi fondasi keberhasilan seseorang dalam bidang yang diinginkannya yaitu pola pikir (LANRI, 2008: 50). Faktor lain 


yang dapat mengembangkan
potensi diri yakni melalui
lingkungan. Faktor lingkungan
dapat berupa kesempatan, sarana
dan prasarana, dukungan orang
lain, tempat tinggal, status sosial
ekonomi dan sebagainya (Mukti,
$\begin{aligned} & \text { 2003: } 309 \text { ).Melakukan } \\ & \text { pengembangan potensi diri } \\ & \text { sebelumnya perlu dilakukan } \\ & \text { pengukuran terlebih dahulu } \\ & \text { diantaranya }\end{aligned}$

mengintropeksi sifat diri pribadi yang dimiliki supaya menjadi lebih baik.Selain itu, orang yang kepercayaan diri bagus pasti memiliki perasaan positif terhadap dirinya, punya keyakinanyang kuat atas dirinya dan punya pengetahuan akurat terhadapkemampuan yang dimiliki.Orang yang punya kepercayaan diribagus, bukanlah orang yang hanya merasa mampu (tetapisebetulnya tidak mampu) melainkan adalah orang yangmengetahui bahwa dirinya mampu berdasarkan pengalaman danperhitungannya (LANRI, 2008: 34-35).Kemudian, keinginan yangkuat untuk memperoleh kesuksesan dalam hidup danmencapai hal-hal besar /baik yang diinginkan. Hal seperti ini, telah dilakukan oleh para generasi muda Buddhis di Kabupaten Jepara yang selalu memiliki kebiasaan untuk mengintropeksi diri atas kesalahan yang diperbuat supaya tidak terulang kembali, selalu mempunyai keyakinan yang kuat untuk mewujudkan potensi dirinya dengan aktif dalam mengikuti kegiatan Sekber PMVBI di Kabupaten Jepara, serta memiliki keinginan yang kuat untuk menuju kesuksesan melalui keaktifan berorganisasi.

Potensi diri yang dimiliki para generasi muda Buddhis di Kabupaten Jepara pada saat ini sudah dapat berkembang biarpun belum maksimal yaitu tentunya dengan melalui kegiatan Sekber PMVBI di Kabupaten Jepara sehingga dapat membawa kepribadian yang baik. Potensi yang dimiliki diantaranya adalah menyanyi, menari, karawitan, belajar bicara di depan umum dan lainnya. Jadi, kegiatan Sekber PMVBI di Kabupaten Jepara merupakan jalan untuk mengembangkan potensi diri yang dimiliki oleh generasi muda Buddhis di Kabupaten Jepara.Dalam hasil penelitian ini 
didapat hasil pengaruh langsung potensi diri terhadap kepribadian sebesar 0,244.Artinya, jika variabel potensi diri dinaikkan satu satuan maka kepribadian generasi muda Buddhis di Kabupaten Jeparaakan meningkat sebesar 0,244.

\section{Pengaruh}

Langsung

Lingkungan Sosial terhadap Kepribadian Generasi Muda Buddhis di Kabupaten Jepara

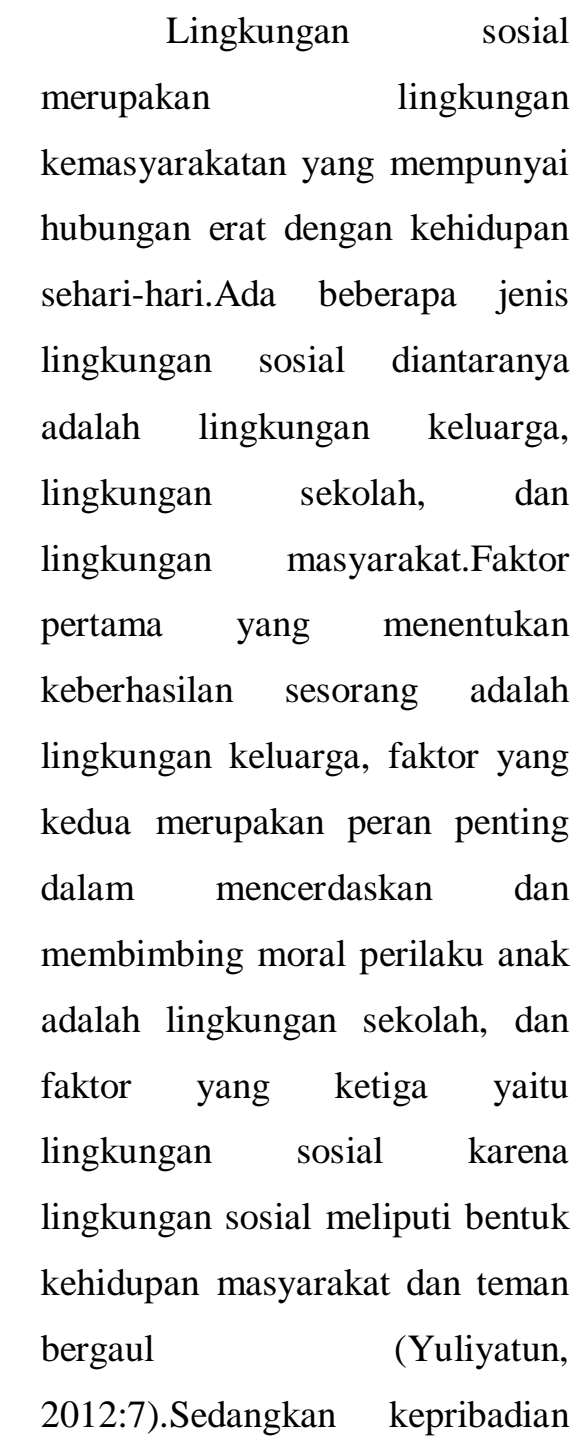

dapat diukur melalui keyakinan individu mengenai kemampuan yang dimiliki, mengatur sumber daya dan mengelola situasi, tetap gigih dalam menghadapi rintangan, memulihkan diri dari keterpurukan (General SelfEfficacy Scale (GSE); penilaian simpati, tenggang rasa, keterandalan, tanggunjawab, keceriaan, kehangatan, asertivitas, adaptasi secara sosial, dan persahabatan (Ego Resiliency Scale); berpikir untuk memahami dan mengevaluasi (Core SelfEvaluations).Dalam uji signifikansi koefisien pengaruh, hasil analisis terhadap hipotesis adalah menerima hipotesis kelima yang berarti ada pengaruh langsung yang signifikan lingkungan sosial terhadap kepribadian.

Purwanto (2003: 28) "mengemukan bahwa lingkungan sosial adalah semua orang atau manusia lain yang mempengaruhi kita". Manusia membentuk pengelompokan sosial diantara sesama dalam upayanya untuk mempertahankan hidup dan mengembangkan

kehidupan.Dalam suatu 
kehidupan sosial manusia juga memerlukan organisasi yaitu sekolah, kelompok masyarakat dan lain-lain (Yuliyatun, 2012: 6-7).Kepribadian merupakan suatu keadaan dalam diri seseorang dimana dapat menentukan bagaimana penampilannya dalam menyesuaikan diri dengan lingkungannya (Winarti, 2007: 4).Berdasarkan hal ini, bahwa lingkungan sosial memang memengaruhi kepribadian generasi muda Buddhis di Kabupaten Jepara.Sehingga, dapat dilihat berdasarkan Path Analisis bahwa lingkungan sosial berpengaruh terhadap kepribadian sebesar 0,228. Artinya, jika variabel lingkungan sosial dinaikkan satu satuan maka kepribadian generasi muda Buddhis di Kabupaten Jepara akan meningkat sebesar 0,228 .

\section{Pengaruh Tidak Langsung} Potensi Diri terhadap Kepribadian melalui Keaktifan Berorganisasi Generasi Muda Buddhis di Kabupaten Jepara

$$
\text { Potensi diri dapat }
$$
diartikan sebagai bakat.Bakat yang dimiliki oleh seseorang merupakan kemampuan alami yang ada dalam dirinya tanpa banyak tergantung pada upaya pendidikan maupun pelatihan.Bakat yang dimiliki seseorang bisa menjadi suatu motivasi yang timbul dari dalam diri seseorang itu sendiri dalam menentukan tujuan hidup atau cita-citanya (Indriyanti, Siswandari \& Elvia 2013: 7).Kepribadian merupakan suatu totalitas psikhophisis yang kompleks dari individu, sehingga nampak di dalam tingkah lakunya yang unik (Sujanto, Halem \& Taufik, 2009).Untuk mengembangkan kepribadian maka hal yang perlu dilakukan adalah pengenalan diri melalui intropeksi, penerimaan umpan balik, pembuatan konsep diri, upaya pembentukan sikap baru, dan upaya pengembangan diri (Winarti, 2007: 19).Dalam uji signifikansi koefisien pengaruh, hasil analisis terhadap hipotesis adalah menerima hipotesis keenam yang berarti ada pengaruh tidak langsung yang signifikan potensi diri terhadap kepribadian melalui keaktifan berorganisasi. 


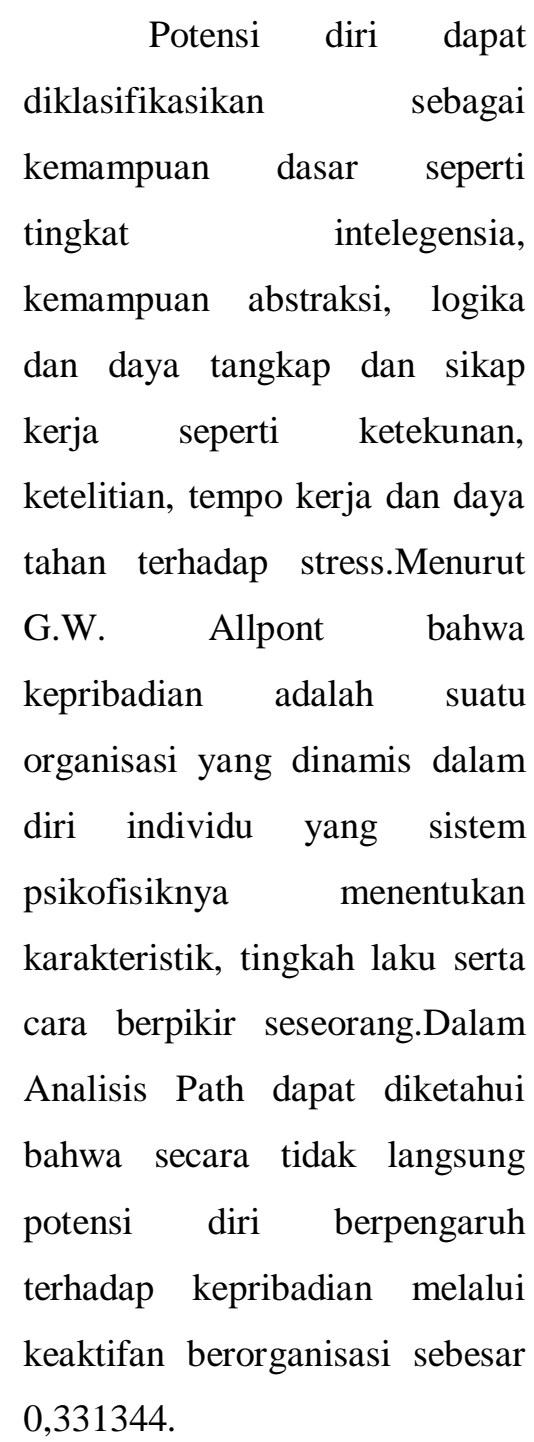

\section{Pengaruh Tidak Langsung} Lingkungan Sosial terhadap Kepribadian melalui Keaktifan Berorganisasi Generasi Muda Buddhis di Kabupaten Jepara

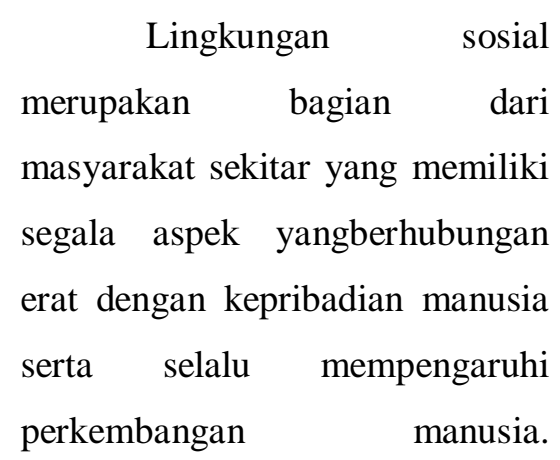

Lingkungan sosial merupakan lingkungan kemasyarakatan yang mempunyai hubungan erat dengan kehidupan sehari-hari.Menurut Winarti (2007: 5) bahwa kepribadian dipengaruhi oleh faktor internal dan eksternal, faktor internal yaitu sifat dari individu supaya dapat berpotensi diri berdasarkan kemampuan yang dimiliki sedangkan faktor eksternal merupakan faktor dari luar yang dapat mempengaruhi kepribadian seperti lingkungan sosial dan keorganisasian.Dalam uji signifikansi koefisien pengaruh, hasil analisis terhadap hipotesis adalah menerima hipotesis ketujuh yang berarti ada pengaruh tidak langsung yang signifikan lingkungan sosial terhadap kepribadian melalui keaktifan berorganisasi.

$$
\text { Lingkungan sosial }
$$
meliputi lingkungan keluarga, lingkungan sekolah dan lingkungan masyarakat. Sedangkan kepribadian itu dapat diukur melalui keyakinan individu mengenai kemampuan yang dimiliki, mengatur sumber daya dan mengelola situasi, tetap gigih dalam menghadapi rintangan, memulihkan diri dari 
keterpurukan (General SelfEfficacy Scale (GSE); penilaian simpati, tenggang rasa, keterandalan, tanggunjawab, keceriaan, kehangatan, asertivitas, adaptasi secara sosial, dan persahabatan (Ego Resiliency Scale); berpikir untuk memahami dan mengevaluasi (Core SelfEvaluations). Berdasarkan Path Analisis bahwa secara tidak langsung lingkungan sosial berpengaruh terhadap kepribadian melalui keaktifan berorganisasi sebesar 0,150804 .

\section{KESIMPULAN}

Berdasarkan uraian dan bab-bab sebelumnya, maka dapat diambil kesimpulan sebagai berikut:

1. Ada pengaruh langsung potensi diri terhadap keaktifan berorganisasi generasi muda Buddhis di KabupatenJeparasebesar 0,624.Artinya, jika variable potensi diri dinaikkan satu satuan maka keaktifan berorganisasi generasi muda Buddhis di Kabupaten Jepara akan meningkats ebesar 0,624.

2. Ada pengaruh langsung lingkungan social terhadap keaktifan berorganisasi generasi muda Buddhis di Kabupaten Jepara sebesar 0,284.Artinya, jika variable keaktifan berorganisasi dinaikkan satu satuan maka keaktifan berorganisasi generasi muda Buddhis di Kabupaten Jepara akan meningkat sebesar 0,284.

3. Ada pengaruh langsung keaktifan berorganisasi terhadap kepribadian generasi muda Buddhis di Kabupaten Jepara sebesar 0,531.Artinya, jika variable keaktifan berorganisasi dinaikkan satu satuan maka kepribadian generasi muda Buddhis di Kabupaten Jepara akan meningkat sebesar 0,531 .

4. Ada pengaruh langsung potensi diri terhadap kepribadian generasi muda Buddhis di Kabupaten Jepara sebesar 0,244.Artinya, jika variable potensi diri dinaikkan satu satuan maka kepribadian generasi muda Buddhis di Kabupaten Jepara akan meningkat sebesar 0,244.

5. Ada pengaruh langsung lingkungan social terhadap kepribadian generasi muda Buddhis di Kabupaten Jepara sebesar 0,228. Artinya, jika variable lingkungan social dinaikkan satu satuan maka kepribadian generasi muda Buddhis di Kabupaten Jepara akan meningkat sebesar 0,228.

6. Ada pengaruh tidak langsung potensi diri terhadap kepribadian melalui keaktifan berorganisasi 
generasi muda Buddhis di

Kabupaten Jepara sebesar

0,331344 .

7. Ada pengaruh tidak langsung lingkungan social terhadap kepribadian melalui keaktifan berorganisasi generasi muda Buddhis di Kabupaten Jepara sebesar0,150804.

\section{DAFTAR PUSTAKA}

Anggawati, Lanny. (2000). Panduan Tipitaka: Kitab Suci Agama Buddha. Klaten: Wisma Sambodhi.

Anonim. (2014). Pengertian Lingkungan menurut para Ahli. Diperoleh tanggal 4 Januari 2016 dari http://dilihatya.com/643/pengert ian-lingkungan menurut-paraahli.

Bodhi. (2010). Samyutta Nikaya Buku 1: Khotbah-khotbah Berkelompok SangBuddha. Jakarta Barat: DhammaCitta Press.

Departemen Pendidikan Nasional. (2008). Kamus Besar Bahasa Indonesia PusatBahasa. Jakarta: Gramedia Pustaka Utama.

Dhammadiro, Sangha Theravada Indonesia. (2005). Paritta Suci. Jakarta: Anggota IKAPI.

Fahmi, Irham. (2013). Perilaku Organisasi (Teori, Aplikasi, dan Kasus). Bandung: Alfabeta.

Indriyanti, Ninuk; Siswandari dan Elvia Ivada. (2013). Faktor-faktor Yang Memengaruhi Mina
Melanjutkan Pendidikan Ke Perguruan Tinggi Pada Siswa Kelas XII Akuntasi SMK Negeri 6 Surakarta Tahun 2013. Jurnalpendidikan Ekonomi-BKK Akuntansi UNS, Vol. 1, No. 2, Hal $1 \mathrm{~s} / \mathrm{d}$ 10.Surakarta: FKIP Universitas Sebelas Maret.

LAN Diklat Kepemimpinan Aparatur Pemerintah Tingkat III. (2014). Pengembangan Potensi

Diri. Jakarta: Lembaga Administrasi Negara Republik Indonesia.

LANRI. (2008). Pengukuran Potensi Diri Modul Pendidikan dan Pelatihan Kepemimpinan Tingkat IV. Jakarta: LAN.

Mahavirothavaro; Mettadewi W \& Dr. Douglas M. Burns. (2009). Meditasi II. Jakarta: CV Yanwreko Wahana Karya.

Mukti, Krisnanda Wijaya. (2003). Wacana Buddha Dhamma. Jakarta: YayasanDharma Pembangunan \& Sangha Agung Indonesia.

Purwanto, Ngalim. (2003). Psikologi pendidikan. Bandung: Rosdakarya.

Sjarkawi. (2006). Pembentukan Kepribadian Anak (Peran Moral Intelektual, Emosional, dan Sosial Sebagai Wujud Integritas Membangun Jati Diri). Jakarta: PT Bumi Aksara.

Slamet, Yulius. (2011). Metode Peneltian Sosial. Surakarta: UNS Press.

Sujanto, Agus; Halem Lubis \& Taufik Hadi. (2009). Psikologi 
Kepribadian. Jakarta: Bumi

Aksara.

Triswianti, Heru. (2010). Analisis Path Untuk Mengetahui Hubungan Kausal Antara Usia, Passing Grade Fakultas, Lama Waktu Penggunaan Facebook, dan Lama Waktu Belajar Terhadap Nilai Akademik Mahasiswa UNS. Skripsi. Surakarta: Fakultas Matematika dan Ilmu Pengetahuan Alam Universitas Sebelas Maret.

Usman, Moh. User. (2009). Menjadi Guru Profesional. Bandung. PT Remaja Rosdakarya.

Widya, Surya. Sasanadhaja. (2001). Dhammapada. Jakarta: Yayasan Abdi Dhamma Indonesia.

Winarti, Euis. (2007). Pengembangan Kepribadian. Yogyakarta: Graha Ilmu.

Yamin, Martinis. (2007). Kilat Membelajarkan Siswa. Jakarta: Gaung Persada Press.

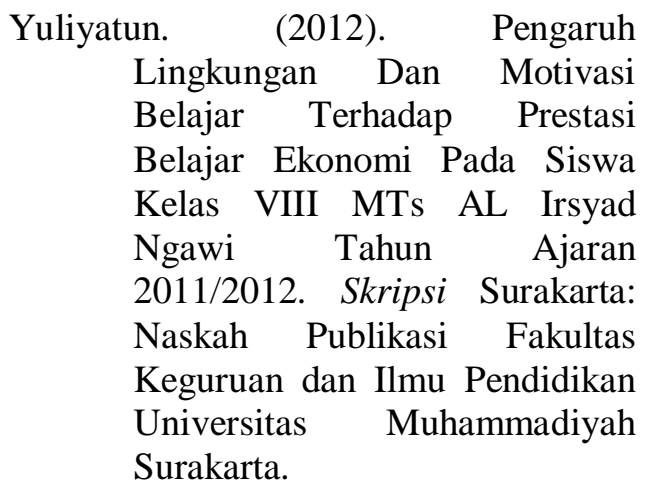

